\title{
MOTIVATIONS AND ATTITUDES TO ENTREPRENEURSHIP IN HUNGARY BASED ON A 2015 EXAMINATION
}

\author{
Csilla Czeglédi ${ }^{1}$, László Hajós ${ }^{2}$, Péter Kollár ${ }^{3}$, Zsuzsanna Kuna Marosné ${ }^{4}$, Andrea \\ Mikáczó Miskolciné ${ }^{5}$, Erika Varga ${ }^{6}$ \\ 1,5,6 associate professor, ${ }^{2}$ professor, ${ }^{3}$ teaching assistant, ${ }^{4} \mathrm{PhD}$ student \\ Faculty of Economics and Social Sciences, Szent István University, Gödöllö \\ E-mail: varga.erika@gtk.szie.hu
}

\begin{abstract}
Summary
Our research was committed to exploring the reasons and attitudes of becoming an entrepreneur in Hungary today. It can be concluded that most respondents could not relate to starting their career as an entrepreneur right after graduation. Reasons include lack of practice or experience, personality flaws (lack of self-assurance), ideas, opportunities and some financial concerns such as lack of capital. To make a positive note, however, we must remark that there were some students who are willing to be entrepreneurs only after collecting some experience, practice and capital.
\end{abstract}

\begin{abstract}
A country's economic success depends on the profitability of its enterprises. Regarding entrepreneurship, however, opinions differ to a large extent. In addition to the social and economic conditions, the significance of entrepreneurship education is also dealt with in our paper. The primary objective is to give an insight into what it is like to be an entrepreneur in today's Hungary. The key findings of students' and entrepreneurs' questionnaires directed at the necessary knowledge, competencies, skills and willingness to set up an enterprise are also presented.
\end{abstract}

Keywords: enterprise, entrepreneurial competencies, Hungary, education, empirical examination

JEL: E71, L26

LCC: LC65-67.68

\section{Introduction}

First, some of the social and economic aspects of Hungarian entrepreneurship are overviewed. Then, the key role and significance of entrepreneurial education is outlined followed by the summary and main findings of our primary research. The qualitative part includes questionnaires filled in both by active entrepreneurs and students of higher education who will be the entrepreneurs of the future followed by some conclusions drawn and recommendations made.

The socio-economic development of a nation is dependent on knowledge, innovation, and entrepreneurship to a great extent.

According to the EU's definition "Entrepreneurship is a key competence for growth, employment and personal fulfilment. Entrepreneurship refers to an individual's ability to turn ideas into action. It includes creativity, innovation and risk taking, as well as the ability to plan and manage projects to achieve objectives. This supports everyone in day-to-day life at home 
and in society, makes employees more aware of the context of their work and better able to seize opportunities, and provides a foundation for entrepreneurs establishing a social or commercial activity" (European Commission, 2006).

An issue for debate is whether entrepreneurs are born with some innate characteristics or it can be learnt via training and education. In the latter case training and education costs incurred for the sake of becoming an entrepreneur can be considered as human capital investment. Human knowledge evolves as the result of a long, costly process, which is like an investment process (Petőné Csuka, 2015).

In an economic sense, being an entrepreneur in Hungary has some benefits as the market rates are low and enterprises can obtain relatively cheap credit nowadays and also there is a wide range of project application opportunities and sources to both establish or develop companies. In the past few years it has become significantly simpler to set up an enterprise but the issue of becoming an entrepreneur does not solely depend on macroeconomic indicators.

Our paper examines the special features of entrepreneurs on the one hand; and characteristics, reasons, objectives, motivations as well as attitudes from the students' part to become an entrepreneur under the current Hungarian economic/market conditions, on the other hand.

\section{Entrepreneurial environment}

When analysing the entrepreneurial environment in Hungary, the Central Statistical Office ( $\mathrm{KSH}, 2017)$ makes note of the following influencing factors:

- demographic overview,

- labour market data,

- education,

- standard of living,

- macroeconomic data,

- industrial performance, and

- data on the environment and energy.

We are going to provide a short review of the demographic situation, the labour market, education, the standard of living and macroeconomic data as in our opinion these are the factors that are very likely to influence the entrepreneurial environment and have a direct impact on the willingness of becoming an entrepreneur.

While analysing the demographic environment it was pointed out by the Hungarian Central Statistical Office that the population started to decline in 1981 and due to its continuous decrease in the 1990s it reached its low point in 1999. In terms of natural decline, the process was accelerated between 2009 and 2012 followed by a slowdown between 2012 and 2014 and again, it has been accelerating since $2014^{1}$. Despite the decreasing tendency of mortality since 1993 it is still high. The population of Hungary amounted to 9 million 799 thousand on 01 January 2017 which is 31.2 thousand fewer than in the previous year ${ }^{2}$.

This figure reflects an unfavourable position of labour supply. In the past five years both employment and unemployment rates have significantly been improving. Between 2013 and 2017 the rate of employment rose from $51.2 \%$ to $59.3 \%$ while unemployment rate decreased

\footnotetext{
${ }^{1}$ https://www.ksh.hu/docs/hun/xstadat/xstadat_hosszu/h_wdsd001a.html

${ }^{2} \mathrm{http}: / /$ www.ksh.hu/docs/hun/xftp/idoszaki/mo/mo2016.pdf
} 
from $10.2 \%$ to $4.2 \%$, which has surpassed the EU average. The number of job vacancies has been on the rise.

The education level of the population has been improving as in $201632 \%$ had a general certificate of secondary education while the ratio of those with a higher education degree was $24 \%$ for the age group between 25 and $64^{3}$.

Regarding standard of living gross average salaries were $6.1 \%$ higher in 2016 than in 2015 while consumer prices increased by $0.4 \%$ in 2016 as of $2015^{4}$.

In terms of entrepreneurial willingness, the number of enterprises was increasing from 420.671 in 2016 to 450.901 in 2017 which equals to a 7\% -rise. According to the statistical data of the Hungarian Central Statistical Office (HCSO) most enterprises take the form of SMEs that play a significant role in the economy, job creation and boosting employment alike. Of the 2.7 million employees at enterprises approximately 2 million (72\%) works for SMEs and 66\% are individual entrepreneurs as $95 \%$ of SMEs are made up by micro enterprise with fewer than 10 employees.

The economy, politics and society have a profound impact on education, which basically determines entrepreneurship and the willingness of becoming an entrepreneur. At the same time, however, skills and competences also count.

The EU has worked out such an action plan that is aimed at such Union and member state measures that support entrepreneurship in Europe based on the following three pillars:

- entrepreneurship education and development of trainings;

- establishing proper business environment;

- $\quad$ showing examples and targeting certain groups.

Several EU-surveys show that $15-20 \%$ of secondary school students formerly involved in mini company programmes will establish an enterprise later. Students involved in entrepreneurial education will have developed business knowledge and sense, which means improving their basic skills and attitude including creativity, initiative, endurance, teamwork, understanding risks and developing a sense of responsibility. This is the entrepreneurial mindset that will make action from ideas and significantly improve employability.

Nastase (2012) found that university education strengthens the ability of innovation and entrepreneurial potentials.

Egerova et al. (2017) pointed out a slight degree of entrepreneurial willingness among students who studied entrepreneurship in business training programmes. They also showed that the family has a significant impact on entrepreneurship. However, no correlation was found between practice and entrepreneurial willingness. Their findings indicated that self-efficacy was ranked slightly higher by those who had participated in entrepreneurship education in comparison to those who had not.

According to Malebana and Swanepoel (2014) universities also serve as a good basis for entrepreneurship. However, students stated to have shortage of creativity, risk taking and entrepreneurial knowledge.

\footnotetext{
${ }^{3}$ http://www.ksh.hu/docs/hun/xftp/idoszaki/mo/mo2016.pdf

${ }^{4} \mathrm{http}: / /$ www.ksh.hu/docs/hun/xftp/idoszaki/mo/mo2016.pdf
} 
Varga (2015) also stated in her examinations that most correspondent and full-time students would like to improve their language knowledge, IT skills and entrepreneurial spirit mainly. To be a successful entrepreneur requires flexibility, good sense of decision making, discretion, risk taking and endurance that universities should train and teach. In terms of motivations for selecting jobs we could find that students need practice orientated courses and visiting instructors' lectures s find them important in their studies. (Kozma, 2013; Kozma et al., 2012; Csehné et al., 2017)

Benneworth and Osborne (2015) found out that entrepreneurial education was not on the list of priorities although the European Commission recommends its inclusion in the curricula.

Of course, there is a need for the natural intuitive abilities arising from the entrepreneurs' personalities, however, the pre-designed resource combinations, the collision of opportunities and strengths, the conscious inventory of threats and risks will help the efficiency of the planning and organizational process. While processing the case study, it was experienced that a good idea on its own is generally not enough for success; it is necessary to combine it with conscious decision-making activity in order to separate the possible and the desired solutions (Kozma-Gyenge, 2015).

\section{Material and methods}

Our primary examination deals with exploring the reasons, motivations, willingness, objectives and attitudes of entrepreneurship in today's economic and market environment of Hungary. In the research both qualitative and quantitative methods were applied to explore the reasons and motives behind. Data were collected in 2015 in the form of questionnaires filled in by active ongoing entrepreneurs $(\mathrm{n}=18)$ on the one hand, and the would-be entrepreneurs, i.e. the students in higher education $(n=297)$, on the other hand.

We were aiming at replying to the four research questions drafted at the beginning.

- How do the respondents assess the conditions of running an enterprise in Hungary?

- What reasons and factors in the background played a role in establishing an enterprise?

- What knowledge, skills and abilities are necessary to run a business?

- To what extent is willingness expressed by career starters for setting up an enterprise?

Our primary objective with the questionnaire was to explore the motivations of establishing an enterprise and the difficulties of running it. Closed questions and attitude related statements that had to be answered on 5-point Liker scales were applied in the questionnaire as the Likert scale provides the respondents with options from which they select the one that best aligns with the view such as the extent how much they agree or disagree with a statement.

The following part summarises our samples used for the examination in short. First, the sample of the entrepreneurs is presented followed by that of the students.

First, let us give an insight into some socio-demographical features of the respondents.

Half of the respondents were younger than 40 while the other half was older. Twenty-five percent were women and $75 \%$ men. Fifty percent have been entrepreneurs for more than 10 years and $61 \%$ have had employees. Thirty-eight percent have set up several enterprises but at present 84 percent have only one business. Seventy-five percent have a degree in higher education. Eighty-three percent work in the service sector. Seventy-eight percent regarded their 
academic achievement above the average. Family patterns and background in setting up an enterprise was not significant for the respondents (only for 50\% of them).

The other examined sample was the group of students.

Altogether we received 297 assessable questionnaires filled in by the students of Szent István University. Sampling was non-representative, accidental and it resulted in $68 \%$ female and $32 \%$ male respondents; $76.1 \%$ bachelor students and $23.9 \%$ master students or at a higher level. Seventy-eight and a half percent of the respondents are full time students and $21.5 \%$ are parttime students.

\section{Results}

\section{Results of the entrepreneurs' questionnaire}

Figure 1 illustrates the strategic attitude of entrepreneurs, which concludes that the entrepreneurs selected were not flexible enough; instead, they tended to stick to their original ideas. They were characterised by examining business models and using resources sensibly. For the company's smooth operation high-level HR, financial, strategic and managerial knowledge (including crisis management), communication and marketing knowledge are essential. The average number of points to the statements concerned is below 3. Networking, i.e. social capital, is also of vital importance.

The product/service of the responding entrepreneurs do not differ from the standard (2.5 points) so this also underpins the importance of planning and strategic operation.

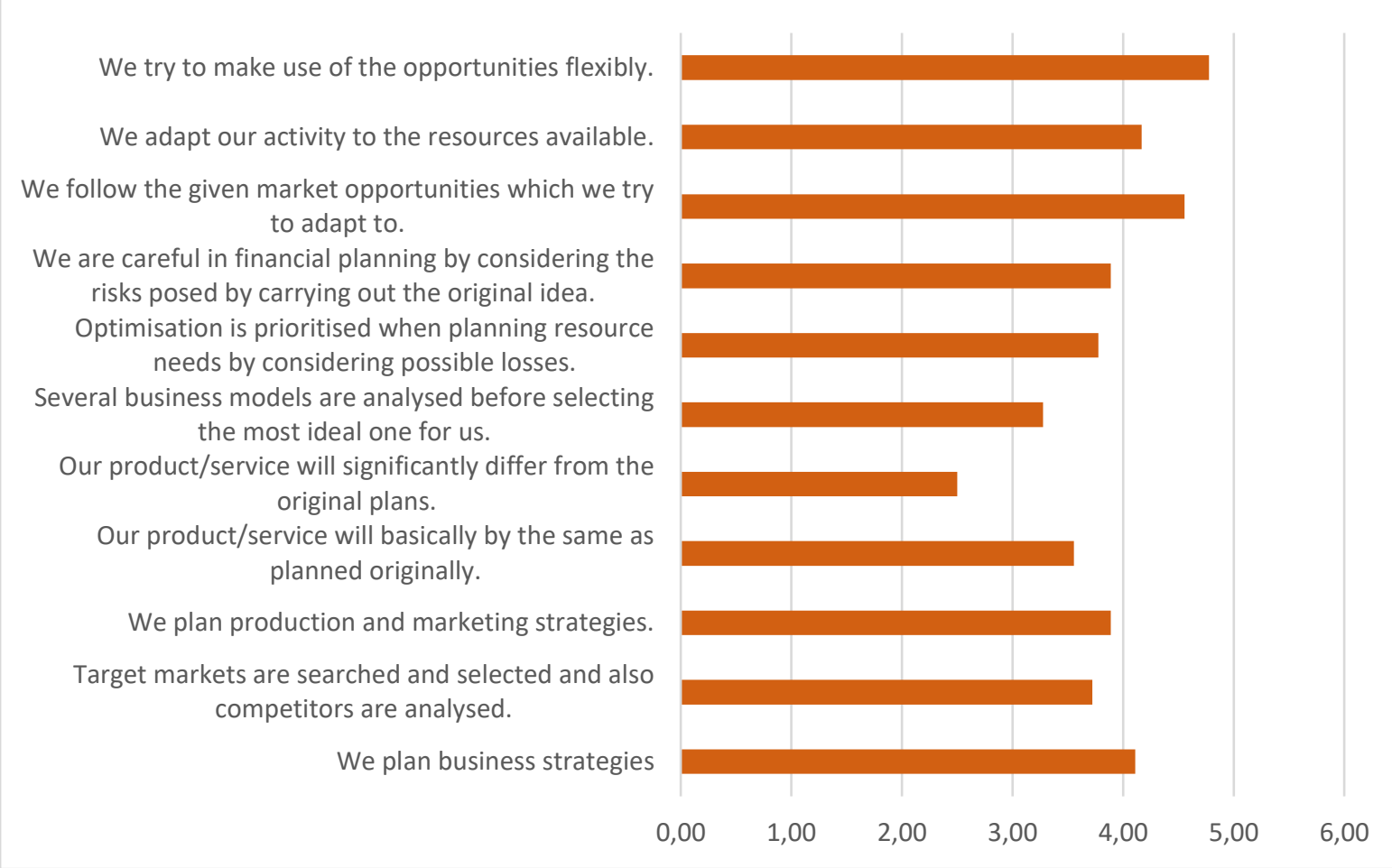

Figure 1 Parts of the strategic attitude of the examined entrepreneurs (mean on a 5-

Source: authors' own research degree scale) 
This result may also suggest that the Hungarian enterprises are not creative enough. Entrepreneurs follow existing business models and produce products and provide services that proved to be a success for other companies. In our opinion creativity could be gradually developed starting from the kindergarten to higher education and even at workplaces. Encouraging children, students and employees to find better solution for an existing problem by being creative and cooperative is of vital importance.

Figure 2 presents the motivations of setting up a business. Unfortunately, the role of higher education was regarded to be less and less enterprise-friendly (an average of 2.78 points). A minor role was played by the family (another business person in the family as a role model) on setting up an enterprise (an average of $2.67 \%$ ), but the family as a supportive environment is important (an average of 3.83), similarly to colleagues (an average of 3.5) but the most important impacts are made by friends (an average of 4.0). During the in-depth interviews the role of making friends while studying in higher education was stressed when it later comes to social capital. However, it is undoubtedly the original business idea that supports the process of becoming an entrepreneur the most.

The role of an invited guest to university in setting up a business is very weak. The reason might be that such an event rarely happens although successful entrepreneur may provide enthusiasm to the students in addition to being their role model. This method should be used more frequently, but it is very important that the guest be authentic rather than a successful entrepreneur.

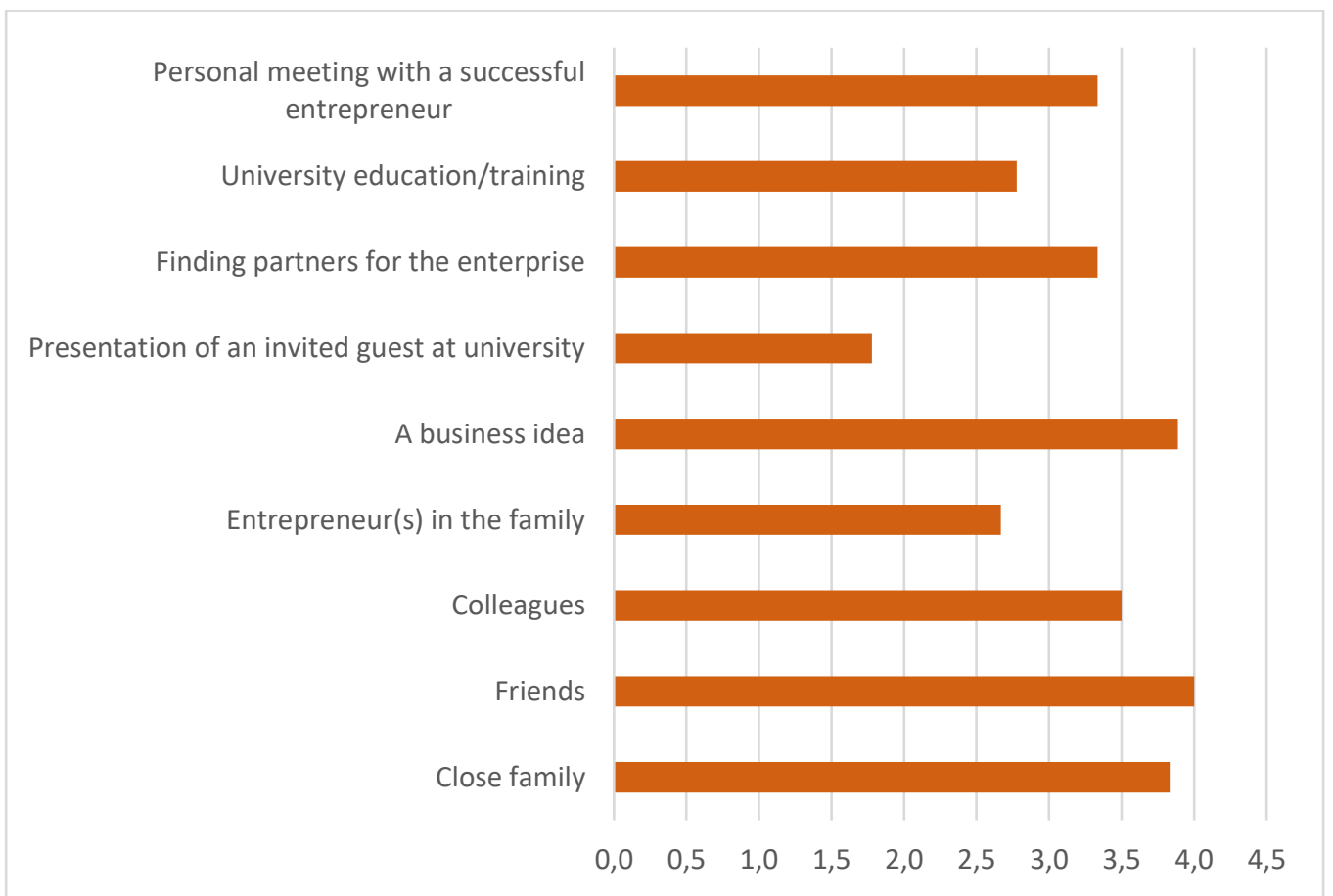

Figure 2 The motivation of the examined entrepreneurs to set up a business (mean on a

Source: authors' own research 5-degree scale)

\section{Results of the students' questionnaire}

Most of the students (83.2\%) have had work experience and only $16.8 \%$ lacked any experience. More than half (52.9\%) are employed at present while 47.1 are unemployed or between jobs and $14.8 \%$ are or were entrepreneurs (freelancers or company owners). The areas of study were 
also analysed in the research: $37.0 \%$ are engaged in technical or other practice-oriented areas, $36.4 \%$ study business/management while $7.7 \%$ are in natural sciences and $18.9 \%$ in other areas.

We also examined how much time the respondents devoted to the enterprise (such as business plans, establishing a company, finances of small enterprises etc.) and studying Business/Management and Entrepreneurship on a 5-degree scale ranging from very little to rather little, medium amount and quite much to very much in their opinion. The results are presented by Figure 3 .

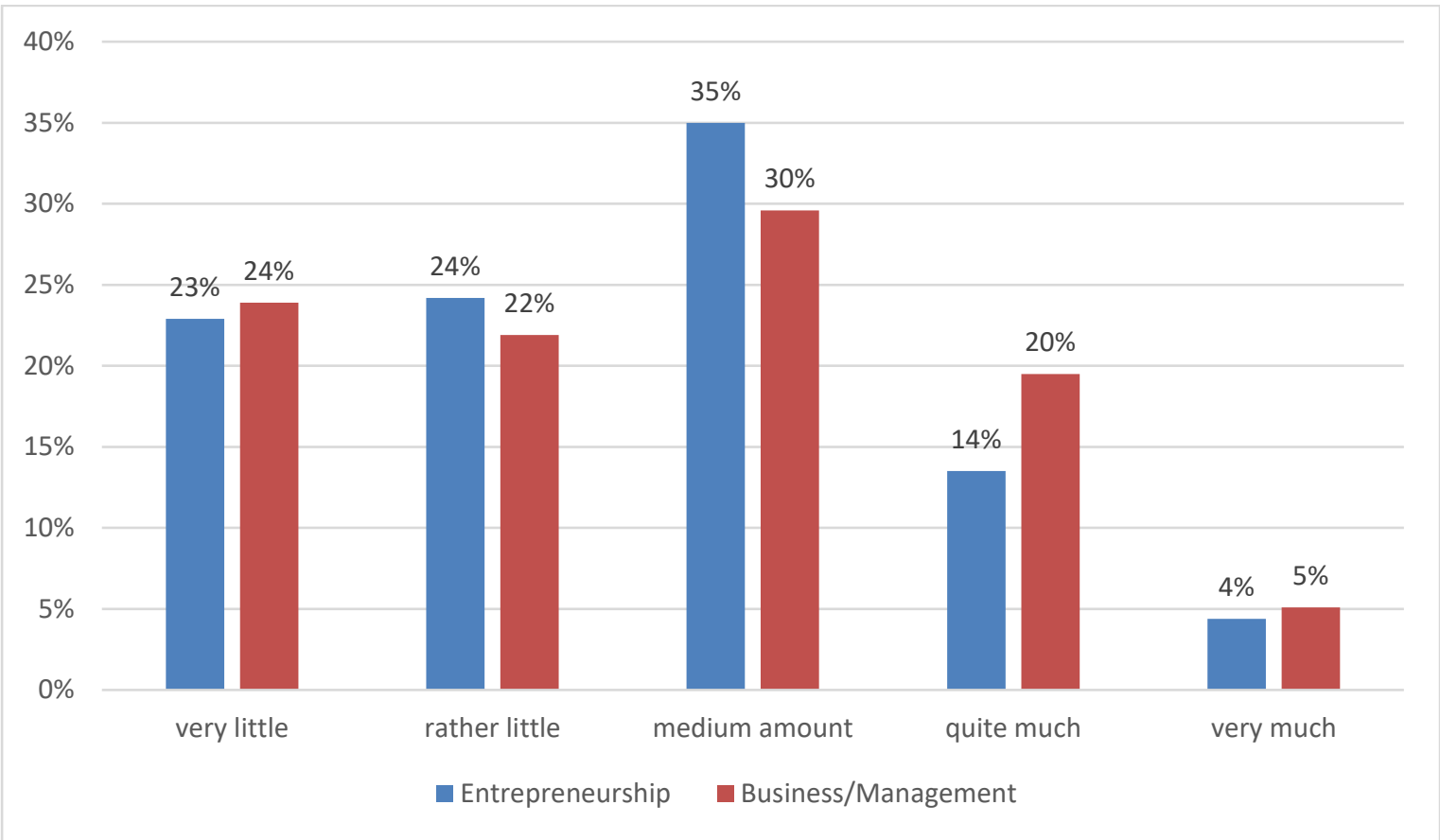

Figure 3 How much time is devoted to the enterprise and studying Business/ Management and Entrepreneurship? (\%)

Source: authors' own research

Based on the figure it can be concluded that the respondents typically spend little time on studying management and only $18 \%$ devoted quite much or very much time on Entrepreneurship and 25\% Business/Management, respectively. This is of special importance considering the fact that more than $36 \%$ of the respondents study in business programmes. Even though their curricula include subjects on business and entrepreneurship, however, they still feel they spend only little time on these disciplines.

The area or industry where the graduates would like to work was also analysed. Figure 4 shows that the respondents would opt for being an employee in the private sector right after graduation and expressed low level of willingness either to being employed in the non-profit sector or being an entrepreneur. When it comes to the 5-year plans of the current students, the private sector is still the most attractive for them while the statement 'I would like to be the (co-) owner of a company 5 years after graduation' received 1-point higher value. 


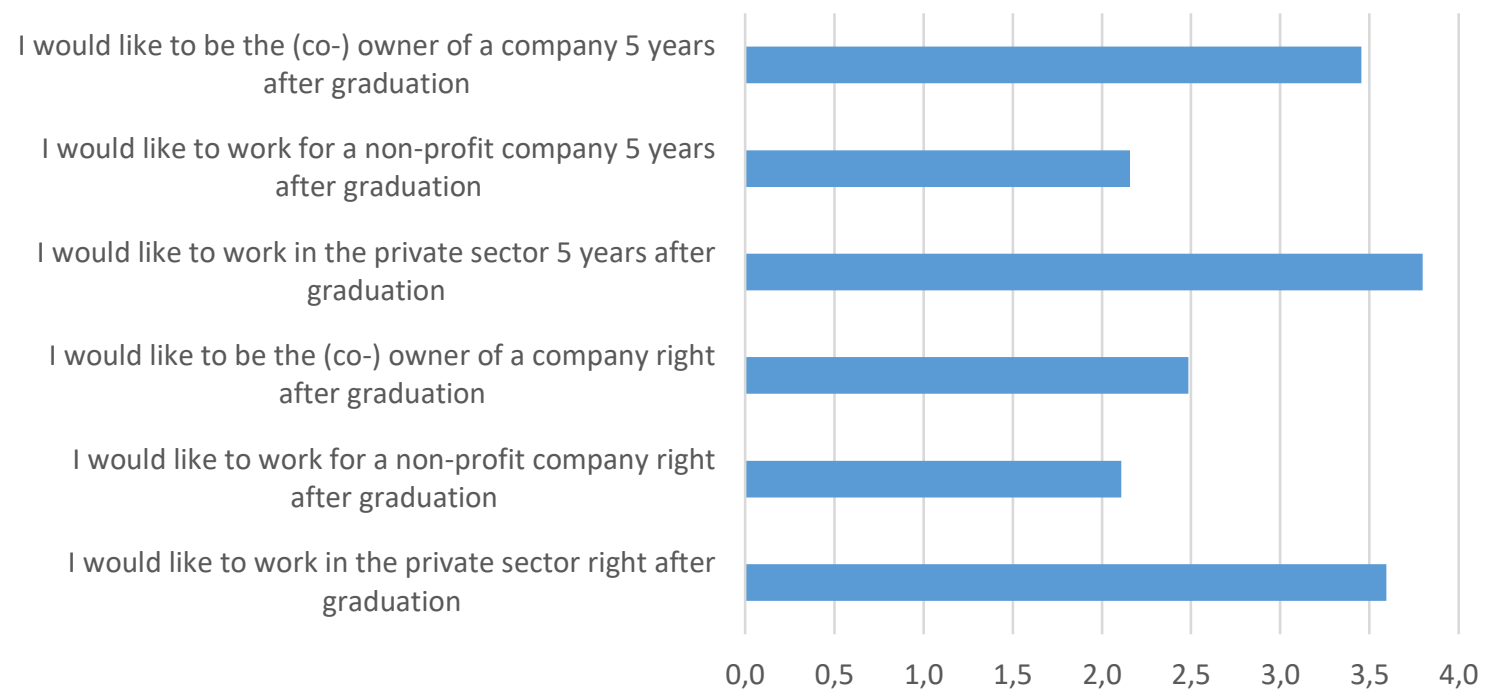

Figure 4 To what extent do you agree with the statements in the figure? (mean on a 5-

Source: authors' own research degree scale)

Furthermore, we also analysed what factors influence the statements below and to what extent, and also an answer was sought whether gender or work experience affect career plans and if there is an entrepreneurial pattern in the immediate environment to follow.

Table 1 Respondents' career plans after graduation (mean on a 5-degree scale)

\begin{tabular}{|c|c|c|c|c|c|c|c|}
\hline & & $\begin{array}{l}\text { right after } \\
\text { graduation } \\
\text { in the } \\
\text { private } \\
\text { sector }\end{array}$ & $\begin{array}{c}\text { right after } \\
\text { graduation } \\
\text { at a } \\
\text { nonprofit } \\
\text { organisation }\end{array}$ & $\begin{array}{c}\text { right after } \\
\text { graduation } \\
\text { as (co)owner } \\
\text { of a } \\
\text { company }\end{array}$ & $\begin{array}{l}5 \text { years after } \\
\text { graduation } \\
\text { in the } \\
\text { private } \\
\text { sector }\end{array}$ & $\begin{array}{c}\text { 5years after } \\
\text { graduation } \\
\text { at a } \\
\text { nonprofit } \\
\text { organisation }\end{array}$ & $\begin{array}{c}\text { 5years after } \\
\text { graduation } \\
\text { as } \\
\text { (co)owner } \\
\text { of a } \\
\text { company }\end{array}$ \\
\hline \multirow{2}{*}{ gender } & male & 3.69 & 2.00 & 2.72 & 3.82 & 1.97 & 3.46 \\
\hline & female & 3.54 & 2.17 & 2.34 & 3.78 & 2.27 & 3.45 \\
\hline \multirow{2}{*}{$\begin{array}{c}\text { work } \\
\text { experience }\end{array}$} & Yes & 3.64 & 2.13 & 2.48 & 3.80 & 2.15 & 3.49 \\
\hline & No & 3.40 & 2.00 & 2.50 & 3.78 & 2.20 & 3.30 \\
\hline \multirow{2}{*}{$\begin{array}{l}\text { entrepreneur } \\
\text { in the } \\
\text { environment }\end{array}$} & Yes & 3.91 & 2.02 & 2.67 & 3.85 & 2.04 & 3.69 \\
\hline & No & 3.24 & 2.21 & 2.28 & 3.74 & 2.29 & 3.19 \\
\hline
\end{tabular}

Source: authors' own research

Data reflect all the three hypothetical differences. Willingness to establish an enterprise and being employed in the private sector is stronger in the case of men. Willingness to set up a company is stronger if there are entrepreneurs in the immediate environment, e.g. in the family. Work experience also correlates strongly and has a beneficial impact on both entrepreneurial willingness and working in the private sector.

We also examined what the respondents' opinion was on establishing an enterprise. The students' attitude was examined on a semantic differential type scale. On the basis of the results it can be concluded that the respondents regard setting up a company generally useful and the think it is worth doing it as this is something positive. The data of Table 2 serve as a very good summary. 
Table 2 Students' opinion on establishing a company on a 5-degree scale (\%)

\begin{tabular}{|c|c|c|c|c|c|c|}
\hline & \multicolumn{5}{|c|}{ In general, establishing a company on a 5 -degree scale is } & \\
\hline & 1 & 2 & 3 & 4 & 5 & \\
\hline useless & $2.4 \%$ & $1.7 \%$ & $31.6 \%$ & $30.6 \%$ & $33.7 \%$ & useful \\
\hline $\begin{array}{l}\text { there is no } \\
\text { point }\end{array}$ & $4.7 \%$ & $6.4 \%$ & $39.7 \%$ & $33.0 \%$ & $16.2 \%$ & it is worth it \\
\hline negative & $4.0 \%$ & $5.1 \%$ & $33.3 \%$ & $29.6 \%$ & $27.9 \%$ & positive \\
\hline
\end{tabular}

\section{Source: authors' own research}

The following part analyses to what extent students are self-confident and certain they are in performing some of the tasks in running an enterprise presented by Figure 5. Respondents assessed these activities on a scale from 1 to 5 where 1 meant being "the least able" and 5 being "the most able" categories (Figure 5).

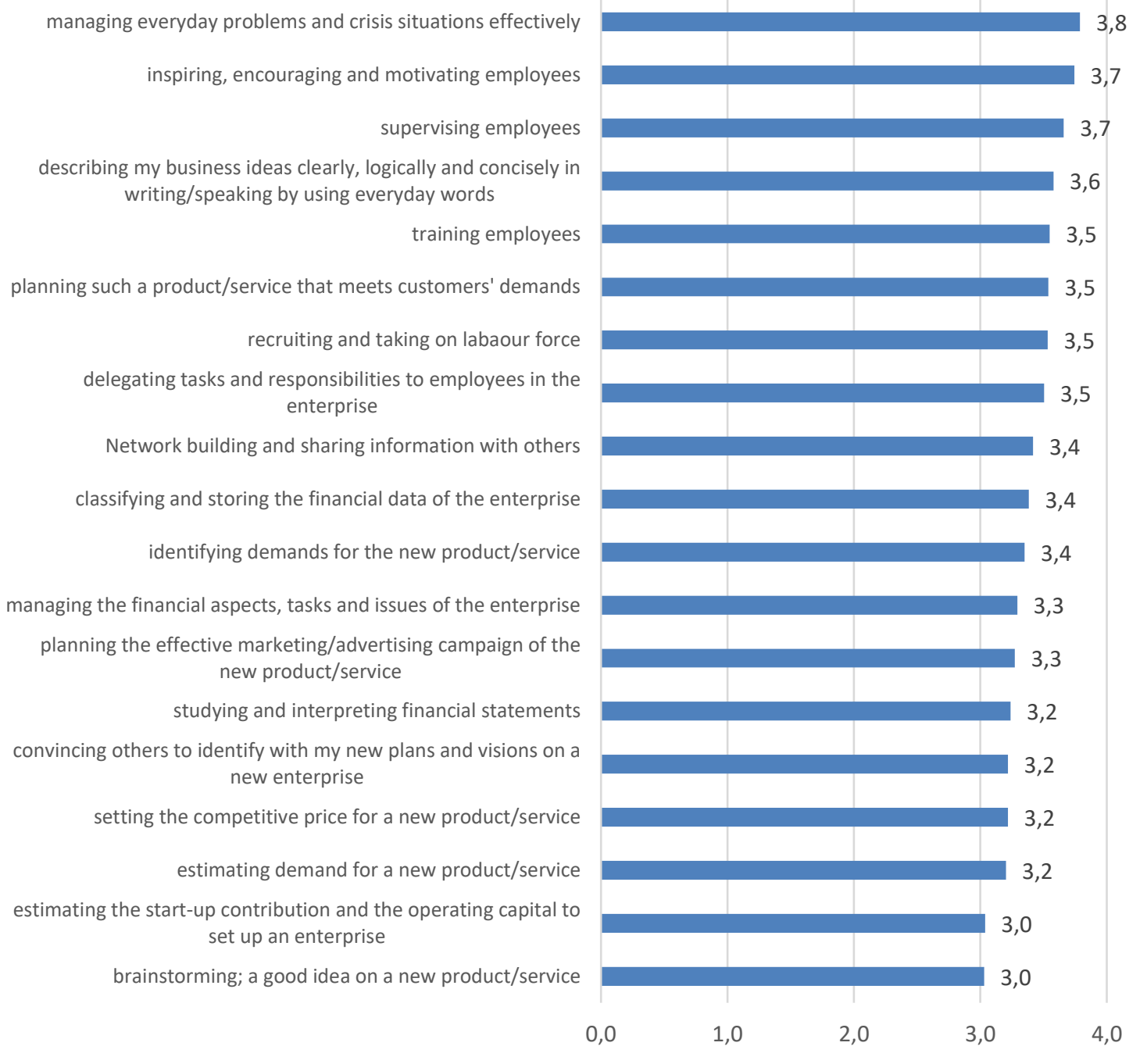

Figure 5 The self-confidence of students in performing activities at the enterprise (mean on a 5-point Liker scale)

Source: authors' own research 
The findings reflect that the respondents think they are the most able to manage everyday problems and crisis situations the most effectively, inspiring, motivating and encouraging employees as well as supervising them. They are the least able to study and interpret financial statements, setting the competitive price for a new product/service, convincing others, estimating demand for a new product/service, estimating start up contribution and the necessary operating capital to set up an enterprise as well as brainstorming. It is an interesting fact that values do not go under the average of 3 points in any of the cases. In spite of the fact that the responding students are not generally characterised by wanting to be an entrepreneur in the future, they seem to be quite self-confident in performing the task that are necessary for running an enterprise.

\section{Conclusions and recommendations}

Being an entrepreneur in today's Hungary was made easier due to lower interest rates on the market (easy credit) and more relaxed legal constraints. The education level of the population has improved, which can be a remedy for labour shortage by making use of adult training and alternative re-trainings. However, some other factors could be improved to stimulate entrepreneurship such as reducing taxes (although we can mention the reduction of corporate tax rate to $9 \%$ from 1 January 2017 or social contribution in two phases from $27 \%$ to $22 \%$ from 2017 and to $20 \%$ from 2018, respectively). If the expenditure on research and education as of GDP reached the average of EU-28, entrepreneurial environment and the ratio of entrepreneurs would improve.

Nowadays entrepreneurial environment is always changing, which poses challenges to entrepreneurship. Respondents identified both external and internal (personal) barriers to setting up an enterprise. A more transparent and flexible legal background free from bureaucratic burdens that supports entrepreneurs was recommended. As for internal, personal conditions and requirements they named entrepreneurial spirit, personality, motivation, challenge, independence, professional opportunities and money but unemployment was also mentioned as a deterrent. In terms of personality traits, characteristics and knowledge selfassurance, object orientation, flexibility, a high level of cooperation, communication skills and coping with stress were mentioned. Speaking foreign languages was also thought important together with an adequate level of professional (e.g. financial) knowledge.

Surprisingly, the role of higher education was only mentioned in the context of gaining professional knowledge, project and strategic planning. They also highlighted its role in accumulating social or networking capital which can be essential in setting up an enterprise although they do not think that higher education supports entrepreneurship. Lack of practiceoriented education and failure in presenting best practices and lifelike, real situations were also raised as important issues. The professional content of education should be reviewed and adapted to market conditions. It is also an important remark that personality traits could exclusively be modified by behavioural means (Czeglédi et al., 2016). The development of key competences in the National Framework of Education ${ }^{5}$ (communication, natural sciences, digital, mathematical, social, entrepreneurial, aesthetical-artistic) should be prioritised at all levels of education in practice rather than theory as at present education is dominated by theory.

According to the respondents, it is the business idea that mostly supports the process of becoming an entrepreneur. When setting up an enterprise the existing and functioning family

\footnotetext{
${ }^{5}$ http://ofi.hu/sites/default/files/attachments/mk_nat_20121.pdf
} 
business is less decisive in becoming an entrepreneur. On the contrary, the family as a supportive environment was pointed out to be of high importance.

In conclusion, higher education must play a great role and take responsibility in putting enough emphasis on teaching subjects that are necessary for becoming an entrepreneur when drafting the curricula and assist young graduates as career starters with the first steps in the world of enterprise. Teaching entrepreneurship is not only beneficial in establishing an enterprise, innovative enterprises or job creation but also in other aspects of life. Higher education programmes on developing entrepreneurial mindsets and skills do not only improve entrepreneurship but also the skills that are necessary to realise and make use of opportunities in life. The use of experiential learning methods is of vital importance to improve entrepreneurship and skills, as well. In addition to the traditional methods in higher education, there is need for multidisciplinary, practice-oriented education that also requires restructuring frameworks.

\section{List of references}

1. Benneworth, P. - Osborne, M. (2015): Understanding universities and entrepreneurship education: towards a comprehensive future research agenda https://www.openaire.eu/en/search/publication?articleId=dedup accessed on 28 February 2018

2. Csehné Papp I. - Szabó K. -Schwarczová, L. - Hajós L. (2017): Ocakavania a predstavy „Z” generácie univerzitnych studentov od thru práce. (EXPECTATIONS AND VISIONS OF „Z“ GENERATION OF UNIVERSITY STUDENTS IN RELATION TO THE LABOUR MARKET). Acta Oeconomica Universitatis Selye, 6: (1) pp. 23-38.

3. Czeglédi, Cs. - Hajós, L. - Kollár, P. - Marosné Kuna, Zs. - Miskolciné Mikáczó, A. - Varga, E. (2016): Vállalkozó ismeretek oktatásának lehetőségei, TANULMÁNYKÖTET a 7. BBK előadásaiból, Vol. 2. Óbudai Egyetem, Budapest.

4. Egerova, D. - Eger, L. - Micik, M. (2017): Does entrepreneurship education matter? Business students' perspectives Tertiary Education and Management. ISSN: 13583883 (Print) 1573-1936 (Online) Journal homepage: http://www.tandfonline.com/loi/rtem20 accessed on 28 February 2018

5. European Commission (2006): Implementing the Community Lisbon Programme: Fostering Entrepreneurial Mind-sets through Education and Learning (COM/2006/0033)

6. $\quad$ http://eur-lex.europa.eu/legal-content/EN/TXT/?uri=CELEX:52006DC0033 accessed on 7 March 2017

7. Kozma, T. (2013): A minőségbiztosítás szerepe és fejlesztése a felsőoktatási intézményekben és annak hallgatói értelmezése a gyakorlatban. Doktori disszertáció SZIE GSZDI Gödöllö, 208 p.

8. Kozma, T. - Dunay, A. - Illés, B. Cs. (2012): University degrees versus requirements of the labour market: What should be the students prepared for in higher education? In: Csaba Bálint Illés (ed.) Proceedings of the International Conference on Management of Human Resources, 2012: Volume II. 282 p. Gödöllö, Magyarország, Rosental Kft, pp. 355-361.

9. Kozma, T. - Gyenge, B. (2015): The secret to business success after the crisis a business model in an enterprise. Journal of Central European Green Innovation. 3:(2) pp.

71-82. https://ageconsearch.umn.edu/record/206663/files/Kozma\%20-\%20Gyenge.pdf 
10. Malebana, M.J. - Swanepoel E. (2014): The relationship between exposure to entrepreneurship education and entrepreneurial self-efficacy Southern African Business, 18 (1), 1-26 p.

11. Nastase, C. (2012): The interactions between entrepreneurial education and business. In: The USV Annals of Economics and Public Administration, VOLUME 12, ISSUE 2(16), 7-13. p.

12. Petőné Csuka, I. (2015): Human capital theories from the perspective of education Corporate Social Responsibility and Human Resource Management in V4 Countries. International Scientific Conference. June 4-5, 2015 Nitra, Slovakia. pp. 202-207

13. Varga, E. (2015): A személyes kompetenciák átértékelődése az emberi erőforrás menedzsment és a gazdasági felsőoktatás szemszögéből. PhD értekezés, Szent István Egyetem.

\section{Electronic sources}

1. https://www.ksh.hu/docs/hun/xftp/idoszaki/mo/mo2015.pdf,

2. https://www.ksh.hu/docs/hun/xstadat/xstadat_evkozi/e_qvd018a.html

3. http://ofi.hu/sites/default/files/attachments/mk_nat_20121.pdf 